\title{
How Molinists Can Have Their Cake and Eat It Too*
}

\author{
Godehard Brüntrup and Ruben Schneider
}

INTRODUCTION

Edmund Runggaldier has always pursued the goal of reconstructing positions in the classic tradition of Christian philosophy within the framework of contemporary analytic philosophy. As a Jesuit he will certainly be delighted to see that one of the greatest contributions to philosophy by a fellow Jesuit, Luis de Molina S.J. (1535-1600), finds so much interest in contemporary analytic philosophy. With Alvin Plantinga's influential "The Nature of Necessity" (Plantinga 1974) and David Lewis's possible-world analysis of counterfactuals (Lewis 1973) there were new conceptual tools available to tackle traditional problems in the philosophy of religion, like that of theodicy or that of reconciling the orthodox concept of God with that of libertarian human freedom. This latter topic had already been conceptualized within a rather similar logical apparatus in the late periods of the Schoolmen, the Baroque Scholastics, especially by Molina. It should come as no surprise that analytic philosophers took interest in the work of this great philosopher and theologian (cf. Flint 1998, 122, fn. 1).

The problem of Divine foreknowledge and human freedom bundles many great topics of analytic metaphysics into a focal point: causality and freedom, time and modality, and the semantics and ontology of counterfactuals. In this paper we will try to reconstruct Molina's position within the contemporary analytic debate and specify to what extent Molina's account of freedom can still be counted as a libertarian view: The Molinist claims to be a libertarian and nevertheless grants God full knowledge of future contingents with regard to human freedom. With disbelief many philosophers reply to this double-claim with "you can't have it both ways" or "you can't have the best of both worlds." We try to show that the Molinist can actually "have it both ways." There is a price to be paid, however: the notion of libertarian freedom has to be defined in a way that does not require an open future. In this paper we suggest such a notion based on the mathematical concept of a "choicefunction." 1

\section{OVERVIEW OF THE DEBATE}

The following system of propositions can serve as a prima facie representation of the logical structure of contemporary positions regarding the Divine attributes of omniscience and omnipotence and their relation to human freedom (cf. Rhoda 2007, 301-303). The following four propositions cannot collectively be true. Only certain selective combinations of these four propositions are logically coherent. The denial of at least one of the four propositions is required:

(1) God has the attributes of absolute independence, omniscience and omnipotence.

(2) There are future contingents, the future is causally open.

(3) It is impossible that the future be causally open and epistemically determined for someone.

(4) The future is epistemically open for God.

The Open Theist assumes (2), (3), and (4). Since (4), however, contradicts (1) it has to be denied by the Open Theist. Several theories try to temporalize God's knowledge and thus God Himself (non-

\footnotetext{
* Incidentally, this common English proverb has its earliest recording in the time of Molina. The author is the English playwright John Heywood who was imprisoned for his Catholic beliefs and later fled England to avoid religious persecution. In a collection of proverbs, published by him in 1546, one finds: "wolde you bothe eate your cake, and have your cake?"

1 We will have to assume a certain familiarity with this debate on the part of the reader. It is not possible to give a full theoretical explication of all the technical notions used in this paper.
} 
eternalism). ${ }^{2}$ The denial of (4) is common to Theological Determinism, Analytic Thomism, and Analytic Molinism because they reject the notion of a non-omniscient God (Deus ignorans). However, a further distinction has to be made. Proposition (4) is a logical consequence of (2) and (3). Denial of (4) implies thus the denial of either (2) or (3). The theological determinist denies (2) while holding on to (3), thus claiming strict causal determination of the future. Thomism and Molinism can be subsumed under the negation of (3) while still asserting (2). Thus, they both believe that even though the future is not causally determined, God can still have foreknowledge of it. In Thomism this is explained by an eternalist concept of time in combination with a specific understanding of causality (cf. Craig 1988, 166-118): future contingents cannot be known as future events; rather, God contemplates them sub specie eternitatis as presently given to Him. He knows tenseless propositions with definite temporal indexicals. For the Thomists ${ }^{3}$ this does not entail that God is in any way determined by temporal events, His aseity is uncompromised: all events, including free decisions and actions, are pre-moved (praemotio physica) and pre-determined (praedeterminatio physica) by the prime cause. ${ }^{4}$ This is also the medium (medium quo) by which God has knowledge of future contingents.

Molinism rejects the Thomistic explanation which is based on eternalism and praemotio physica. The latter, according to the Molinist, is a first step on a slippery slope towards determinism. Molinism assumes only a rather general entitative concurrence of God, one that remains indifferent with regard to free acts of the human will (concursus simultaneus et indifferens): "the 'primary cause' of everything is God. Yet a human action is free only if the creaturely agent gives God's 'general concurrence' that makes that action possible a particular direction by causally contributing to it as well" (Jäger 2011, 89). In order to safeguard God's sovereignty over his creatures, Molina postulates a Divine knowledge of certain counterfactuals: the theory of middle-knowledge. He distinguishes three specifications of Divine knowledge: first, the pre-volitional knowledge of all necessary truths and all possible worlds (scientia naturalis); second, the post-volitional knowledge of all contingent actual truths, including future ones, after creation (scientia libera); third, and in between the other two, the pre-volitional knowledge of all contingent truth-values of all counterfactuals or pre-factual conditionals, especially those involving the counterfactuals of freedom (scientia media): "If creaturely essence $\mathrm{P}$ were instantiated in non-determining complete circumstances $\mathrm{C}$ at time $t$, the instantiation of P would (freely) do A" (Flint 1998, 47). (To formalize this, we will be using the notation of David Lewis: "C $\square \rightarrow$ A." " $\square \rightarrow$ " denotes the "would"-implication: "If it were the case that $\mathrm{C}$, then it would be the case that A". This has to be distinguished from the "might"-implication " $\mathrm{C} \diamond \rightarrow \mathrm{A}$ ": "If it were the case that $\mathrm{C}$, it might be the case that A," cf. Lewis 1973, 2.) Neither the counterfactuals of freedom nor the Divine act of creation cause (by efficient causation) free human actions. God's sovereignty is established by the fact that He has access to this middle knowledge logically prior to His free choice in the act of creation. God can freely create circumstances (or worlds) and place free creatures in them in such a way that they freely choose under those circumstances those free actions that fulfill the Divine creative plan.

The scheme of the four propositions enabled us to systematize the positions on God's omniscience and the openness of the future. When it comes to the problem of freedom and determinism regarding human actions, another way of systematization is helpful. It is a scheme of three propositions forming a logical trilemma. Any two of the three propositions are logically consistent, but the third has to be denied (cf. Flint 1998, 22-23; Brüntrup 2000, 102-10):

2 A weaker version of Open Theism could replace (3) by this assumption: It is impossible that the future be open and all propositions about the future have definite truth values. The future would be unknown to God because the truthvalues of propositions concerning the future have not yet been determined. Since knowledge implies truth, God knows all knowable propositions and is thus omniscient (cf. Rhoda 2007, 303-304). This position runs into a conflict with the Law of Conditional Excluded Middle.

3 We refer here to the historically influential Bánnezian brand of Thomism (Domingo Bánnez, 1528-1604).

4 Can the free human will resist the pre-determined praemotio by God? The Thomists have a rather complex answer to this question which we cannot address here. In a nutshell: God causes these free actions contingently and as contingent events. God predetermines the free will in its free nature. In sensu diviso there is even in a pre-moved will the potentiality to resist, at least counterfactually. In sensu composito, however, the finite will is unable to make another choice (cf. Thomas Aquinas, De Ver, q. 6, a. 4, ad 8; q. 23, a. 5, ad 3). 
(a) Some human actions are free.

(b) All humans actions are determined by circumstances and events which are outside of the agent and not under the agent's control (remote past and laws of nature, Divine foreknowledge and predestination).

(c) It is impossible that a free action be determined by circumstances and events which are outside of the agent and not under the agent's control.

Theological Determinism denies propositions (a) and affirms (b) and (c). This is the claim that there are no free human actions. Open Theism denies proposition (b) and asserts (a) and (c); it is clearly a libertarian position. Bánnezian Thomism denies (c) and affirms (a) and (b) with respect to determination by God. It can thus be classified as compatibilism. In the literature Molinism is commonly labeled as a libertarian position (cf. Flint 1998, 24-34). This implies the denial of (b) and the affirmation of (a) and (c). However, classifying Molinism as a libertarian position gives rise to some controversial claims which will be systematically addressed in what follows.

\section{THE ANTI-MOLINIST CONSEQUENCE ARGUMENT}

It is our contention that if Molinism is to be a libertarian position, the Molinist had better consider the Consequence Argument against compatibilism a valid argument. The conclusion of the Consequence Argument is that nobody has a free choice about anything, assuming that we live in a deterministic world, and the past and the laws of nature cannot be changed. We will label this argument "CA Comp" (cf. Van Inwagen 1983, 96-98, 147). The problem of Divine foreknowledge and human freedom is logically analogous to the problem of freedom and determinism. It is of considerable signifiance in this context that some arguments against Molinism have the logical structure of the Consequence Argument against compatibilism. In that case the Molinist might be forced to use similar strategies to those put forth by the compatibilists who argue against the Consequence Argument.

Let us call such an argument against Molinism "CAMol" (cf. Perszyk 2003). Let C be a set of circumstances and A be an action, then let " $\mathrm{C} \square \rightarrow \mathrm{A}$ " be any true counterfactual of freedom known by Divine middle-knowledge. We also define a "Choice-operator":

$\mathrm{Ch}_{x} p:=$ " $p$ obtains and it was in $x$ 's power to take an action A such that A occurs and therefore $p$ is true" (cf. Rugel 2006, 41-44).

We define the "No-Choice-Operator" in the standard way:

$$
\mathrm{N} p:=p \wedge\left(\forall x: \neg \mathrm{Ch}_{x} \neg p\right)
$$

For any free action the following principle holds:

(F) $\quad \mathrm{A}$ is free $: \Leftrightarrow \exists x: \mathrm{Ch}_{x} \mathrm{~A} \leftrightarrow \neg \mathrm{NA}$

We also assume the rules $\alpha$ and $\beta$, well-established in the literature:

$(\alpha) \quad \square p \rightarrow \mathrm{N} p$

(B) $\mathrm{N} p, \mathrm{~N}(p \rightarrow q) \vdash \mathrm{N} q$

We can then argue against Molinism in a way strictly parallel to the classical Consequence Argument (cf. Perszyk 2003, 148):

$\begin{array}{lll}(\mathrm{CAMol}, 1) & \text { 1) } \square\{[(\mathrm{C} \square \rightarrow \mathrm{A}) \wedge \mathrm{C}] \rightarrow \mathrm{A}\} & \text { Consequence of Molinism } \\ \text { 2) } \square[(\mathrm{C} \square \rightarrow \mathrm{A}) \rightarrow(\mathrm{C} \rightarrow \mathrm{A})] & \text { from 1) } \\ \text { 3) } \mathrm{N}[(\mathrm{C} \square \rightarrow \mathrm{A}) \rightarrow(\mathrm{C} \rightarrow \mathrm{A})] & \text { 2), } \alpha \text {-rule } \\ \text { 4) } \mathrm{N}(\mathrm{C} \square \rightarrow \mathrm{A}) & \text { Fixity of middle knowledge } \\ \text { 5) } \mathrm{N}(\mathrm{C} \rightarrow \mathrm{A}) & \text { 3), 4), } \beta \text {-rule } \\ \text { 6) } \mathrm{NC} & \text { Axiom } \\ \text { 7) } \mathrm{NA} & \text { 5), } 6), \beta \text {-rule }\end{array}$


But since principle (F) holds for any free action, $\mathrm{CA}_{\mathrm{Mol}, 1}$ implies the incompatibility of Molinism and libertarian freedom. Due to difficulties with the original Van Inwagenian Consequence Argument, especially with the $\beta$-rule, many improved versions have been advanced in the literature. For reason of simplicity, elegance and the relative lack of problem cases, we thus suggest the following definitions (cf. Brüntrup 2000, 112; Rugel 2006, 56):

$$
\begin{aligned}
& \mathrm{N}^{*} p:=p \wedge\left(\forall x: \neg \mathrm{Ch}_{x}(\diamond \neg p)\right) \\
& \left(\beta^{*}\right) \quad \mathrm{N}^{*} p, \square(p \rightarrow q) \vdash \mathrm{N}^{*} q
\end{aligned}
$$

The Anti-Molinist Consequence Argument can now be rephrased:
$\left(\mathrm{CAMol}, 1^{*}\right)$
1) $\mathrm{N}^{*}[(\mathrm{C} \square \rightarrow \mathrm{A}) \wedge \mathrm{C}]$
Fixity of middle knowledge and antecedents
2) $\square\{[(\mathrm{C} \square \rightarrow \mathrm{A}) \wedge \mathrm{C}] \rightarrow \mathrm{A}\}$
Consequence of Molinism
3) $\mathrm{N}^{*} \mathrm{~A}$
1), 2), $\beta^{*}$

In his "Molina on Foreknowledge and Transfer of Necessities" (2011), Christoph Jäger draws on an informal version of this argument. As a stronger and more coherent replacement for Molina's notion of "accidental necessity" (of propositions known by middle knowledge), Jäger introduces the notion of "causal-impact necessity" or "CI-necessity" (cf. Jäger 2011, 84-88):"

(CI-necessity) A metaphysically contingent proposition or state of affairs $p$ is CI-necessary for a given agent at $t$ iff it is not within the agent's power at $t$ to contribute causally to some thing that constitutes, or grounds, a necessary or sufficient condition for $p$. (Jäger 2011, 88).

The principle $(\mathrm{F})$ can thus be read as:

(F') For libertarian freedom with respect to an action A, it is necessary that A is not CInecessary for the agent.

The transfer principle given by Jäger is accordingly:

$\left(\beta\right.$ ') "If it is CI-necessary for a given subject at $t$ that $p$, and $p$ [strictly ${ }^{6}$ entails $q$, then it is CI-necessary for that subject at that $q$ " (Jäger 2011, 92).

Jäger's overall argument now runs like this (slightly modified by us, cf. Jäger 2011, 91)

$(\mathrm{CAMol}, 2)$

1. At any time in S's life it is CI-necessary for S that God knows (prevolitionally and from extra-temporal eternity) via middle knowledge that $\mathrm{S}$, when placed in circumstances $\mathrm{C}$ at $t$, would freely do A.

2. God's knowing (prevolitionally and from extra-temporal eternity) via middle knowledge that $\mathrm{S}$, when placed in circumstances $\mathrm{C}$ at $t$, would freely do A, entails [strictly] that $\mathrm{S}$, if placed in $\mathrm{C}$ at $t$, freely does A.

3. Hence, it is CI-necessary for $\mathrm{S}$ that, when placed in $\mathrm{C}$ at $t, \mathrm{~S}$ freely does $\mathrm{A}$.

4. $\mathrm{S}$ is not free in doing A freely when placed in $\mathrm{C}$ at $t$.

The inference from (2) to (3) is based on the $\beta$ '-rule, and the inference from (3) to (4) is based on the definition of libertarian freedom given in (F') above. The CI-necessity of a proposition

5 "A proposition $p$ is accidentally necessary at $t$ iff $p$ is (i) metaphysically contingent and (ii) true at $t$ and every moment after $t$ in every possible world that has the same history as our world at $t$ " (Jäger 2011, 86), or, as defined by William of Sherwood: "That is accidentally necessary which neither now or in the future can be false, but once might have been false" (Sherwood, Introductiones, 11, 34).

6 That is, by metaphysical necessity (there is no possible world, such that God knows a counterfactual of freedom in it, and the appropriate event does not occur if the the relevant circumstances have been actualized). This clarifying and relevant addition can be found in Jäger 2010, 313 . 
$p$ implies, that the subject has no choice such that possibly $\neg p$ (i.e. $\neg \mathrm{Ch}_{x}(\diamond \neg p)$ ). Thus, the $\beta$ '-rule operating in $\mathrm{CA}_{\mathrm{Mol}, 2}$ is as strong as $\beta^{*}$ in $\mathrm{CAMol}_{1} *$.

These inferences can, just as the classical replies of the compatibilists to $\mathrm{CA}_{\mathrm{Comp}}$, be undermined by a refutation of the relevant $\beta$-rules. This is the route taken by Jäger, following an earlier argument by Freddoso (cf. Jäger 2011, 92-96; Freddoso 1988, 53-62). The appropriateness of this move seems to be vindicated by the fact that Molina himself seemingly rejects modal transfer principles in Concordia 4.52.34:

"For in such a case, even if (i) the conditional is necessary (because in the composed sense these two things cannot both obtain, namely, that God foreknows something to be future and that the thing does not turn out that way), and even if (ii) the antecedent is necessary in the sense in question (because it is past-tense and because no shadow of alteration can befall God), nonetheless the consequent can be purely contingent" (transl. Freddoso, Molina 1988, 189). ${ }^{7}$

A correct analysis of this passage is, however, more difficult than one might initially think. It is by no means clear whether Molina wants to reject a transfer principle of the form $(\mathrm{N} p, \square(\mathrm{p} \rightarrow \mathrm{q})$ $-\mathrm{N} q)$, or whether he rather intends to reject an inference of the form $(\mathrm{N} p, \square(\mathrm{p} \rightarrow \mathrm{q}) \vdash \square q)$ with respect to metaphysical necessity in the consequent. And also, in the same paragraph 34 Molina argues against this inference by counterfactual situations: "For if, as is possible, the opposite of the consequent were going to obtain, then the antecedent would never have obtained beforehand [...]." It is, however, not the topic of this paper to settle these exegetical questions.

Jäger argues that Molina not only rejects the transfer principle as a matter of fact, he is also committed to this rejection to avoid inconsistencies. Jäger tries then to refute the transfer principle by making use of Ravizza's overdetermination objection (cf. Ravizza 1994). A fact $H$ is assumed to be caused by two independent events $E_{1}$ and $E_{2}$. Each of the two events is by itself sufficient for the truth of $H$. Now let $E_{1}$ be a free choice of an agent $S$. With regard to the moral responsibility of $S$ for the occurrence of $H$, the following inference is possible: (i) $S$ is not responsible that $E_{2}$; (ii) $S$ is not responsible that $\left(E_{2} \rightarrow H\right)$; (iii) Thus: $S$ is not responsible that $H$. However, (iii) is false. Since the inference from (i) and (ii) to (iii) relies on a $\beta$-transfer principle, and both premises are true, the transfer principle must be false. Transfer principles can be defended against this line of argument. Jäger himself offers an improved transfer principle for the case of moral responsibility which is immune to overdetermination objections (Jäger 2006, 14-19). The more general problem of these counterexamples to $\beta$-principles, regardless of whether they are directed against moral responsibility or the no-choice operator, is this: If $H$ follows deterministically and $S$ is responsible for $H$, then compatibilism is already assumed. Assuming compatibilism in a refutation of a version of the Consequence argument, an argument that is meant to defeat compatibilism, is obviously a petitio principii. If, however, $H$ follows indeterministically, then this assumption of indeterminism in a line of reasoning that is - against a version of the Consequence Argument - ultimately meant to prove the compatibility of freedom and determinism is pointless (cf. Brüntrup 2000, 109).

\section{COUNTERFACTUAL POWER OVER MIDDLE KNOWLEDGE}

A much more important problem in the general rejection of the $\beta$-rule seems to be that the Molinist would have to reject not only $\mathrm{CA}_{\mathrm{Mol}, 2}$ or $\mathrm{CA}_{\mathrm{Mol}, 1}$ but also $\mathrm{CA}_{\mathrm{Comp}}$ along with it since in all those arguments the same structure of $\beta$-rules is at work (the objection made by Jäger stems from the debate about $\mathrm{CA}_{\text {Comp }}$ ) - which is not admissible for the Molinist (as a libertarian), because the assumption of the validity of CAComp is a necessary (if not sufficient) condition for being a libertarian. If the Molinist, along with Jäger, rejects the $\beta$-rule's validity it becomes difficult for him to maintain a libertarian position.

7 "Tunc enim, esto condicionalis sit necessaria, quia in sensu composito cohaerere non possunt ista duo, quod Deus aliquid praesciat futurum et illud non eo modo eveniat, et esto antecedens illo modo sit necessarium, quia praeter itum et quia in Deum nulla possit cadere vicissitudinis obumbratio, nihilominus consequens potest esse mere contingens." 
So another way taken in the literature to refute the anti-Molinist Consequence-Argument consists not in the rejection of the $\beta$-rule but in the repudiation of the premises, that is to deny the statement that we have no choice at all regarding the truth values of the counterfactuals of freedom concerning us. Even if we are unable to exert any causal power on the knowledge of God and its contents (for this would deny the independence of God), we could still possess counterfactual "power" over it, since the scientia media's counterfactual conditionals for their part have no causal influence on our actions and are only contingently true. Rather, they are explanatorily prior to our actions but logically and causally insufficient for them (cf. Morriston 2001; Perszyk 2003, 141): lacking causal power over a truth $p$ is not the same as lacking counterfactual power over $p$. The Molinist has the option to allow this counterfactual power only over the counterfactuals of freedom: in $\mathrm{CA}_{\text {Comp }}$ he does not have to allow counterfactual power regarding the remote past $\mathrm{P}$ and the laws of nature L as compatibilists do, for the past and laws, contrary to the counterfactuals of freedom, are not subject-related. Indeed, Van Inwagen models his definition of determinism $\square[(\mathrm{P} \wedge \mathrm{L}) \rightarrow \mathrm{Fu}-$ ture] explicitly in such a way that $\mathrm{P}$ is a state of the past before the existence of free subjects (cf. Schneider 2009, 23). This counterfactual power over counterfactual conditionals and, along with it, over the scientia media is explicitly conceded by Molina himself; he writes on middle knowledge: "[it] would be different in God if, as is possible, created free choice were by its innate freedom going to turn itself to the opposite part [...] ([...] aliter se haberet in Deo, si liberum arbitrium creatum pro sua innata libertate, ut potest, in oppositam partem foret inflectendum [...])" (Concordia 4.52.31, cf. 4.52.30, 32 and 34). ${ }^{8}$

This can be specified further (cf. Perszyk 2003, 140f.): if $\mathrm{M}_{0}$ is the state of God's middle knowledge which contains the counterfactual $\mathrm{C} \square \rightarrow \mathrm{A}$, and is counterfactually dependent on a decision on our behalf, then this means that the counterfactual power for the backtracking counterfactual $\neg \mathrm{A} \square \rightarrow \neg \mathrm{M}_{0}$ is true. But that also means that - if $\mathrm{M}_{0}$ holds - it is not possible for an agent to actually choose $\neg \mathrm{A}$ (within the "physical state" of being created, the scientia media is virtually unavoidable for it precedes our temporal existence, cf. Ramelow 1997, 263) since this would entail the impossibility of counterfactual power over the counterfactual conditional, as can clearly be seen in the logic for counterfactuals by David Lewis:

$$
\left(\neg \mathrm{A} \wedge \mathrm{M}_{0}\right) \rightarrow\left(\neg \mathrm{A} \diamond \rightarrow \mathrm{M}_{0}\right) \leftrightarrow \neg\left(\neg \mathrm{A} \square \rightarrow \neg \mathrm{M}_{0}\right)
$$

Within the logic of counterfactuals it is impossible for us to have counterfactual power over the scientia media (i. e. that the appropriate back-tracker be true) and still, assuming $\mathrm{M}_{0}$ holds, to be able to act differently in the actual course of the world. The Molinist is therefore unable to claim both. To put it differently: if we have counterfactual power over the knowledge of God it is, under actualized circumstances $\mathrm{C}$, logically if not actually possible to act in a different manner from the one which is contained "beforehand" in God's middle knowledge. Our actual actions are accidentally but not metaphysically necessary. There are possible worlds containing actions that originated from free choices and the scientia naturalis contains (among other things) all possible worlds in which an individual $P$ decides differently under the same circumstances $\mathrm{C}$ (reasons, dispositions etc.) than in the (assumedly) true counterfactual $\mathrm{C} \square \rightarrow \mathrm{A}$, namely in choosing $\neg \mathrm{A}$. Therefore it is logically or metaphysically possible that there should be different courses of the world than those provided actually and contingently by the middle knowledge.

\section{THE INDIVIDUAL ESSENCE AS "NOTIO COMPLETA"}

\subsection{Libertarianism without open future}

8 Cf. also Concordia, 4.52.10: "For if created free choice were going to do the opposite, as indeed it can, then God would have known that very thing through this same type of knowledge, and not, what He in fact knows [Si namque liberum arbitrium creaturam acturum esset oppositum, ut revera potest, idipsum scivisset per eandem scientiam, non autem quod reipsa scit]." 
Now, does this mean that the Molinistic approach will slide into a form of compatibilism? For compatibilism also chooses a way out of CA Comp using counterfactual power, counterfactual power over the laws of nature and the past in this case. But the crucial difference between a compatibilist and Molinist is that for the Molinist neither the past nor the laws of nature nor Divine knowledge influence the free choice causally in any way. For the Molinist the rational agent is the cause of his decisions completely within himself - he is an independent cause in the sense of agent causation. The Molinist therefore has to maintain CA Comp along with the libertarian and at the same time has to reject $\mathrm{CA}_{\mathrm{M} o l}$. This means especially that the Molinist has to assume the $\beta$-rule to be valid and to set the crucial difference in the possibility of counterfactual power: while counterfactual power over the past and the laws of nature has to be rejected it has to be assumed regarding Divine knowledge, which is of a completely different nature from the past and the laws of nature. ${ }^{9}$

Nevertheless there is a crucial difference between Molinism and the classical libertarian position: a possible world's future regarding free actions may be causally open within the scientia media (sentence (2) of the initially introduced system of sentences) but still the future does not constitute a "garden of forking paths" (Kane 2005, 7) in a (possible or actual) creation presented by the scientia media and the scientia libera: The courses of action are decisively predefined. If God were to rewind time by some units to a point before the actual choice and would let it proceed again, the resulting decision would always be the same. So, if we analyse freedom in a libertarian sense we can discern two crucial aspects of freedom for the classical libertarian (cf. Morriston 2001, 30-31) of which the Molinist can accept only one:

(I) Agent causation and autonomy: Nothing (else) caused the agent to act as he did.

(II) Principle of alternate possibilities: Exactly as things were at the time of action, the agent could have refrained from doing the act.

Molinism embraces Principle (I) as a crucial element of freedom against determinism (and the trilemma of freedom initially does not require more for a libertarian position). Principle (II), formulated as (F) or (F') above, does not hold for the Molinist in the actual world. We are facing a libertarianism without an open future. This means that the definiteness of the course of decision is not synonymous with lawlike determination: The decisions originate in the individual himself and are not heteronomous but still follow an unambiguous path through time. Using "Frankfurt-style counterexamples," Bergmann (2002) argues that the "Principle of alternate possibilities" is not necessary to ascribe created beings responsibility for their actions. ${ }^{10}$

\subsection{Intentional pre-existence and "notio completa"}

But how is this possible? Without venturing into the exegesis of the concept of freedom in Molina's Concordia on the point of its concept of freedom, it still is possible to trace a historical line of Molinist concept formation which renders some insight into our systematical question:

For Molina within the counterfactual $\mathrm{C} \square \rightarrow \mathrm{A}$ there is no deterministic connection between $\mathrm{C}$ and A. From Molina's point of view, the only connection between them is formed by the supercomprehension of God (cf. Concordia 4.49.11, 4.52.33): the indeterminateness of the freedom of choice is balanced by the superdeterminateness of Divine knowledge which infinitely transcends its object of knowing, and therefore "supercomprehends" it. The infinite power of representation of the Divine essence, by which God knows everything without requiring external information, and the infinite depth of His knowledge replace, as it were, the lacking determinateness of the human will (cf. Ramelow 1997, 56; Craig 1988, 178f.). ${ }^{11}$ From this concept of supercomprehensive knowledge we can draw a line to the Leibnizian term conceptus completus, or the individual idea of a free agent.

9 Perzyk 2003 extensively discusses the problems of this distinction, but we cannot explore these in this paper. If Molinism is supposed to be a libertarian position, then it is inevitably is bound to this distinction.

10 Frankfurt-cases have been invoked explicitly against the tansfer-principles. As counterexamples they are only valid against $\beta$ though, not against $\beta^{*}$ (cf. Brüntrup 2000, 110-111).

11 For the Molinist, this means a receptive, not a creative form of knowledge on this point. 
This connection can be traced best by quoting the Molinist Hieronymus Fasolus S.J. (1568-1639) (cf. Ramelow 1997, 228):

"According to Molina [...] the free cause [...] cannot be known in a perfect manner, unless everything that is contained in this cause is also known, as well as everything what can possibly be caused by it, what has been caused by it, will be caused by it, and would be caused by it; for the effects too, and indeed all these effects, are something of this cause. So he who perfectly knows the cause, necessarily also knows these effects that depend on it in any respect whatsoever [...]. But it is evident that this perfect knowledge must be infinite regarding future effects." (In primum partem Summae D. Thomae Commentariorum, T.2, Lyon 1629, 269a, cf. Knebel $1991,3) .^{12}$

Even if he rejects the concept of a middle knowledge in God, Leibniz has a very similar intuition regarding the Divine foreknowledge:

"God preserves our being and continually generates it, namely in such a way that we encounter thoughts spontaneously or freely in that order which is carried by the concept of our individual substance and in which it could be forseen from all eternity" (Discours de métaphysique, $\S$ $30) .{ }^{13}$

Without having to follow Leibniz in his particular theory of individual ideas we can use the quotations by him and Fasolus as a backdrop for forming the following model: The individual essence ${ }^{14}$ of a free actor $P$ pre-exists intentionally in the Divine mind logically prior to God's act of creation. For a formal exposition, let $U$ be the set of possible conditions $C, C \in U$, and let $A$ be a set of possible actions to be taken and $M$ a set of subsets of $A,\left\{A_{i}: i \in I\right\} \in M$. Then, by His scientia natural$i s$, God knows which sets of actions are coherent with which conditions, formulated as a function from $U$ to $M$ :

$$
\begin{gathered}
F_{P}: U \rightarrow M, \\
F_{P}(C)=\left\{A_{i}: i \in I\right\}
\end{gathered}
$$

The actor $P$ to be created should be free, therefore several choices among actions coherent with respect to conditions $U$ are available for him. Formally, he can avail himself of several choice-functions

$$
\text { ch: } M \rightarrow A \text {. }
$$

These choice-functions have sets as arguments and one element of the respective arguments as value: $\operatorname{ch}\left(\left\{A_{i}: i \in I\right\}\right)=A_{C}$, where $A_{C} \in\left\{A_{i}: i \in I\right\}$. The actor to be created has a set of choicefunctions $\mathrm{CH}$ at his disposal: in the strict logical sense there are several free choices consistent with the single circumstances and the actors individual essence. This also may be regarded as belonging to God's scientia naturalis.

By His scientia media, God knows which specific choice-function the actor to be created is going to select. So God knows not only the family of choice-functions $\mathrm{CH}$ available to the actor to be created but also which one the actor would select, He knows:

$$
\begin{gathered}
c h^{*} \in C H, \\
c h^{*}: M \rightarrow A, \\
\operatorname{ch}^{*}\left(A_{i}: i \in I\right)=A_{C^{*}} .
\end{gathered}
$$

12 "Mente Molinae [...] causa libera [...] non potest perfectissimo modo obiective cognosci, nisi simul cognoscantur et omnia, quae sunt in causa, et praeterea omnia quae ex causa vel esse possunt, vel erunt, vel sunt, vel fuerunt, vel essent; nam effectus etiam, atque adeo omnes isti effectus, sunt aliquid causae; ergo qui cognoscit perfectissimo modo causam, eius etiam effectus, quavis ratione ab ea pendentes, cognoscat necesse est [...]. Quod autem haec perfectissima cognitio respectu effectuum futurorum esse debeat infinita, patet."

13 For a precise reconstruction of the development of the Leibnizian concept of the individual idea or the "notio completa" within the Molinist debate from the perspective of the age cf. Ramelow 1997, 401-419.

14 Cf. Kvanvig 1986, 122-126. 
In sum, by His middle knowledge, God knows the composed function

$$
S_{P}^{*}:=c h^{*} \circ F_{P}: U \rightarrow A,
$$

the first component being the choice of the actor to be created, and the second simply indicating which actions are coherent with which conditions (within a coherence framework - a possible world - Wo. A world in which $c h^{*} \circ F_{P}$ holds can thereby become actual, i.e. it is a "feasible" world, cf. Flint 1998, 51-54). All these functions, i.e. the conditional connections between $C$ and the $A_{i}$, are pre-volitional for God. Not until God creates one (and for each point in time only one) $C^{*} \in U$ does He have any scientia libera. The scientia libera arises in evaluating the composed function $c h^{*} \circ F_{P}$ at the created condition (the argument $\left.C^{*}\right), c h^{*}\left[F_{P}\left(C^{*}\right)\right]$.

So the free choices originate from the individual's essence instead of receptively being the consequence of external causes. The composed functions $S_{P} *=c h^{*} \circ F_{P}$ present a "Logic of Freedom" inherent in possible beings. Their decisions intentionally anticipated by the Divine mind in the guise of the abstract and therefore trans-temporal essential functions $S_{P}{ }^{*}$ are the medium of knowledge (medium quo) by which God contemplates ${ }^{15}$ the counterfactuals of freedom from His eternal point of view. These functions also provide the truth-makers for counterfactuals demanded by the famous Grounding Objection against Molinism (cf. Flint 1998, 123-126; Hasker 1989; Adams 1977, 30). Since the functions are pre-volitional, the scientia media is not caused by an act of the Divine will, and since they are pre-existent, the actual decisions within the actual creation are also not the cause for the truth values of the counterfactuals (which would mean the aporetical external determination of the actus purus).

\subsection{Man as the image of God}

So creatures in actual reality cannot claim freedom of choice. Therefore, Molinism is able to radically construct man as the image of God, for in classical scholasticism God also does not have "alternative courses of action" within Himself in the strict sense: He does not change and is still free, even the source of all freedom. For Thomas Aquinas, God does not have freedom of choice regarding Himself since he recognises Himself as the absolute good and complete perfection, and therefore necessarily affirms Himself. He only has freedom of choice "ad extra" - what makes the Divine freedom of choice a relation of the perfect being toward imperfect beings, so it cannot be regarded as part of the actual, original freedom of God. Freedom of choice according to Aquinas can thus only be attributed to God in a secondary sense (cf. Schöndorf 2006, 654-655). For the classical Molinist too, God does not have freedom of choice in the actual meaning: the only freedom of choice that could occur within God Himself would be a freedom of the Divine hypostases toward each other by which they freely choose each other (cf. Schöndorf 2006, 658). But for the Molinist Luis Perez, for example, this is explicitly impossible since the Divine persons are logically prior than the choices of God. To prove his point, Perez explicitly refers to Molina himself (cf. Ramelow 1997, 252).

The classical position also does not attribute freedom of choice to the angels and saints in heaven since they are facing the infinite good which is God and necessarily affirm it as their ultimate goal. ${ }^{16}$ True freedom is seen as the striving for the highest good, as well as its affirmation. ${ }^{17}$ The freedom of beings within the world also has its core in this affirmation of the good. But in a fallen world they are possessed by a receptiveness for the deviation from perfection resulting from original sin. Their morally wrong actions in the sinful maze of circumstances within this world are also contained within the functions of their essences as possibilities.

15 Speaking of distinct, finite functions within the Divine mind can of course only be understood modo nostro concipiendi. The Divine mind is not discursive but rather contemplates his "objects" of knowing.

16 Tradition explains the fall of the angels by an initially obscured perception of the absolute perfection on their behalf which enabled them to sin by deprivation.

17 The rejection of the good in this case is synonymous with the loss of freedom, comparable to a drug addict losing his freedom by abandoning himself to the mechanism of evil - he becomes a "slave of sin." 
Within the actual world freedom at its core thus consists in an independent self-realisation of the creature in an internal coherence with itself as well as in a comprehension of the inner logic of its being: "become what thou art." We encounter freedom if the created being acts of its own accord in such a way that is coherent with itself. The created being independently and uncoercedly strives for realising its very own, complete form. ${ }^{18}$

\section{CONCLUDING REMARKS}

We have seen that the Molinist has to accept the consequence-argument CA Comp against compatibilism regarding the determinateness of nature, if he wants to remain a libertarian, while he has to reject the consequence-arguments $\mathrm{CA}_{\mathrm{Mol}}$ against the "compatibility" of Gods foreknowledge and human freedom. But then he is unable to reject the validity of the principles of transfer that are at work in both consequence-arguments. The Molinist has to assume a counterfactual power over the (subject-related) contents of the middle knowledge, while rejecting such a counterfactual influence on the past and the laws of nature. Thus in the actual state of being created, it is only logically and not actually possible to act differently from what is known by the middle knowledge. So the Molinist, as we have seen, has to advocate a libertarianism without open future regarding the actual world: Libertarian freedom is conceived of in a weaker sense, as agent causation with an unambiguous course of action through time. However, this unambiguity is not synonymous with lawlike determination. The possibility of this is modeled best by an intuition shared by Molinists from the time between Molina and Leibniz: within the Divine mind (and only within His mind) there pre-exists an individual idea of a free creature $P$ which contains all of its possible actions, as well as true counteror prefactual conditionals in the form of the function $S_{P}{ }^{*}$. The truth values of these conditionals cannot be ascribed with metaphysical necessity. This function is the counterfactuals' truth-maker before the act of creation, thereby refuting the notorious grounding objection against Molinism.

But this raises the question of a much deeper grounding-objection which does not relate to the question of truth-makers: Where do the functions $S_{P} *$ originate? Are they created by God? Then the scientia media is not pre-volitional. Or is it something that confronts God in a relative form of autonomy from all eternity as the Possibilia in the thought of Suárez do (cf. Mahieu 1921, 229232)? But then, who defines that they are exactly as they are? Are they brute facts? William Lane Craig suggests that a further grounding of the truth values of the counterfactuals of freedom would make freedom impossible (cf. Craig 2001; Davidson 2004, 368), and the same goes for the essential functions $S_{P}{ }^{*}$; they would simply form the fundamental, irreducibly basic elements in the architectonics of Molinistic theory that are founded in the supercomprehension of God, in the infinite depth of His knowledge.

This research was supported by a grant of the John Templeton Foundation, Philadelphia, USA: Analytic Theology Project, Cluster-initiative "Divine Omnipotence, Human Freedom and the Problem of Evil - Towards an Analytic Concept of Theodicy".We wish to express our gratitude to Christina Schneider, LMU, Munich.

\section{REFERENCES}

Adams, Robert 1977 “Middle Knowledge and the Problem of Evil”, American Philosophical Quaterliy 14, $109-117$. Bergmann, Michael 2002 "Molinist Frankfurt-style Counterexamples and Free Will Defense", Faith and Philosophy 19(4), 462-478.

Brüntrup, Godehard 2000 „Der Metaphysische Begriff der Willensfreiheit und das Transferprinzip des Keine-WahlHabens", in Peres, C. and Greimann, D. (eds.), Wahrheit - Sein - Struktur. Auseinandersetzungen mit Metaphysik, New York/Zürich, 102-119.

18 For a criticism of this point cf. again Schöndorf 2006. 
Craig, William L. 1988 The Problem of Divine Knowledge and Future Contingents from Aristotle to Suárez, Leiden. ------ 2001 "Middle Knowledge, Truth-makers and the "Grounding Objection"”, Faith and Philosophy 18, 337352.

Davidson, Scott A. 2004 "Craig on the Grounding Objection to Middle Knowledge”, Faith and Philosophy 21, 365369.

Flint, Thomas P. 1998 Divine Providence. The Molinist Account, Ithaca: Cornell University Press.

Freddoso, Alfred J. 1988 “Introduction”, in Luis de Molina, On Divine Foreknowledge (Part IV of the Concordia), transl. by Alfred J. Freddoso, Cornell University Press.

Hasker, William 1989 God, Time and Knowledge, Ithaca: Cornell University Press.

Jäger, Christoph 2006 „Drei Konsequenzargumente für eine inkompatibilistische Theorie moralischer Verantwortung“, Zeitschrift für philosophische Forschung 60/4, 504-527.

-------- 2010 „Göttlicher Plan und menschliche Freiheit. Vorhersehung und ,Mittleres Wissen“ bei Luis de Molina“, in Buchheim, Thomas u.a. (ed.), Philosophisches Jahrbuch im Auftrag der Görres-Gesellschaft, 117. Jahrgang, 2. Halbband, 299-318.

2011 "Molina on Foreknowledge and Transfer of Necessities", in Tapp, Chr. And Runggaldier, E. (eds.), God, Eternity, and Time, Farnham/Burlington: Ashgate, 81-98.

Kane, Robert 2005 A Contemporary Introduction to Free Will, New York/Oxford: Oxford University Press.

Knebel, Sven 1991 "Necessitas moralis ad optimum. Zum historischen Hintergrund der Wahl der besten aller möglichen Welten“, Studia Leibnitiana 23, 3-24.

Kvanvig, Jonathan 1986 The Possibility of an All-Knowing God, London: Macmillan Press.

Lewis, David 1973 Counterfactuals, Blackwell: Oxford.

Mahieu, Léon 1921 Francois Suarez, sa philosophie et les rapports qu'elle a avec sa théologie, Paris.

Molina, Luis de 1988 On Divine Foreknowledge (Part IV of the Concordia), transl. by Alfred J. Freddoso, Cornell University Press.

Morriston, Wes 2001 “Explanatory Priority and the „Counterfactuals of Freedom”, Faith and Philosophy 18(1), 2135.

Perszyk, Kenneth 2003 "Molinism and the Consequence Argument - a challenge", Faith and Philosophy 20(2), 131-151.

Ramelow, Tilman 1997 Gott, Freiheit, Weltenwahl. Die Metaphysik der Willensfreiheit zwischen A. Perez S.J. (1599-1649) und G.W. Leibniz (1646-1716), Leiden: Brill.

Ravizza, Mark 1994 "Semi-Compatibilism and the Transfer of Nonresponsibility", Philosophical Studies 75, 61-93. Rhoda, Alan 2007 "The Philosophical Case for Open Theism”, Philosophia 35, 301-311.

Rugel, Matthias 2006 Handlung und Freiheit. Analysen zur Akteursverursachung, München: Philosophia.

Schneider, Christina 2009 Metaphysische Freiheit - Kohärenz und Theorie, München: Philosophia.

Schöndorf, Harald 2006 „Ist Willensfreiheit immer Wahlfreiheit?“, in Philosophiae et Musicae, Liber iubilaris Professori Stanislao Ziemianski SJ septuagesimum quintum annum celebranti dicatus, Roman Darowski SJ (ed.), Krakau, 647-658.

Van Inwagen, Peter 1983, An Essay on Free Will, Oxford: Clarendon Press. 